Goldschmidt 2021 Abstract

https://doi.org/10.7185/gold2021.3593

\section{Geochemistry and Zr U-Pb geochronology reveals the involvement of the deep Archean basement rock in Lonar impact event}

\author{
SARANYA R CHANDRAN ${ }^{1}$, SHANIA JAMES ${ }^{2}$ AND SAJIN \\ KUMAR KS ${ }^{3}$ \\ ${ }^{1}$ Department of Geology, University of Kerala \\ ${ }^{2}$ University of Kerala \\ ${ }^{3}$ Michigan Technological University \\ Presenting Author: saranyarchandran.geo@keralauniversity.ac.in
}

Lonar Impact Crater (N 19 $58^{\prime} 35^{\prime \prime}$ and E 76 30'30"), in Central India, is the only well-preserved, simple, bowl-shaped crater carved out in the continental flood basalts on the Earth [1]. It is a $1.88 \mathrm{~km}$ diameter and $150 \mathrm{~m}$ deep Quaternary age circular crater in the $\sim 66 \mathrm{Ma}$ Deccan Basalt. The crater is dated to be $\sim 570 \pm$ 47 ka by ${ }^{40} \mathrm{Ar} /{ }^{39} \mathrm{Ar}$ geochronology [2]. The involvement of Archean basement rocks (equivalent of Peninsular Gneissic Complex-PGC) in the impact event is one of the widely debated topic of the Lonar Impact Crater with a few studies reporting this only based on the geochemical characterisation $[3,4]$. An impactmelt bearing rock from the ejecta layer is the subject of present study. The dark colored, aphanitic melt-bearing rock has many vesicles and smooth glassy blobs within a rugged, slaggy outer surface. Plagioclase and discrete quartz with shock-induced features like conversion to diaplectic glass, well-developed planar deformation features (PDF) and mosaicism have been observed in the petrography. Later Laser Raman spectroscopy revealed the presence of cristobalite. The major and trace element geochemistry of the melt rock is more similar to the target basalt rocks, but at the same time being more fractionated like the basement PGC. The U-Pb geochronology, from the separated zircon grains, revealed a Mesoarchean age (3.0 to 3.1 $\mathrm{Ga}$ ) that was in accord with the PGC. The highly variable REE contents of zircons mostly fall in the transitional trend between magmatic and hydrothermal zircons with majority occupying the magmatic field. These robust evidences, along with the geomorphological parameters like the depth to diameter ratio of the transient Lonar crater, strongly supports the involvement of Archean basement rocks (PGC) in the Lonar impact event, and thereby terminating a longest debated topic.

Figure 1: Graphical abstract of the meteorite impact event at Lonar Impact Crater.

\section{References:}

[1] Fredriksson, K. et al. (1973) Science, 180(4088), 862-864.

[2] Jourdan, F. et al. (2011) Geology, 39(7), 671-674.

3] Chakrabarti, R. and Basu, A. R. (2006) EPSL, 247(3-4), 197-211.

[4] Schulz, T. et al. (2016) MaPS, 51(7), 1323-1339.

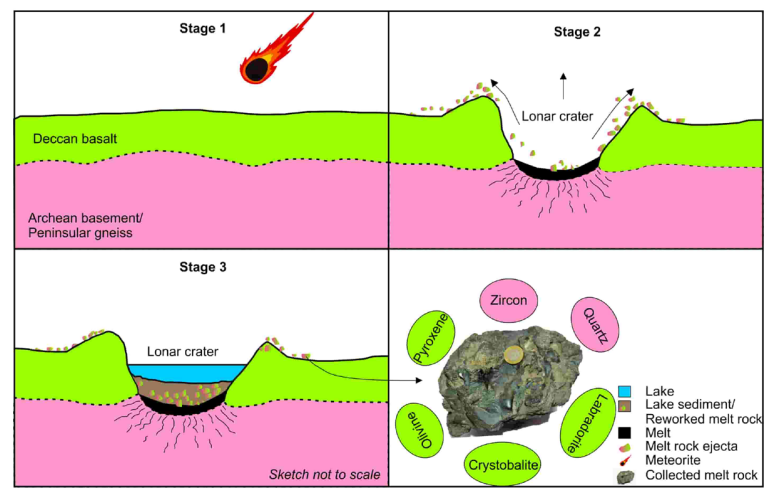

